\title{
Reflections on the Professionalism and Specialization for Counselors in China
}

\author{
Shuo Zhang', Xuan $\mathrm{Xu}^{2}$, Hui Lu ${ }^{3}$, Bin Liu' ${ }^{2}$, Xiaoyu Han ${ }^{1}$, Guishu Yu ${ }^{1}$ \\ ${ }^{1}$ Faculty of infrastructure Engineering, Dalian University of Technology University, Dalian, China \\ ${ }^{2}$ Teaching Affairs Division, Dalian University of Technology University, Dalian, China \\ ${ }^{3}$ School of Software, Dalian University of Technology University, Dalian, China
}

\section{Email address:}

zhangshuo@dlut.edu.cn (Shuo Zhang),xuxuan@dlut.edu.cn (Xuan Xu), luhui@dlut.edu.cn (Hui Lu), laohubinbin@163.com (Bin Liu), 108835693@qq.com (Xiaoyu Han),1002535403@qq.com (Guishu Yu)

\section{To cite this article:}

Shuo Zhang, Xuan Xu, Hui Lu, Bin Liu, Xiaoyu Han, Guishu Yu. Reflections on the Professionalism and Specialization for Counselors in China. Science Discovery. Vol. 4, No. 5, 2016, pp. 320-323. doi: 10.11648/j.sd.20160405.21

Received: September 25, 2016; Accepted: October 31, 2016; Published: November 5, 2016

Abstract: "Communist Party of China Central Committee and State Council's Opinions on Further Strengthening and Improving Ideological and Political Education of College Students" and other programmatic documents clearly put forward to improve the professionalism and specialization level of Counselors. So counselors should base themselves upon own job, pay attention to actual effect, innovate carrier, enhance learning, take 'strengthening morality' as the fundamental work, strengthen the intrinsic development, give full play to the role of network as the main channel, rose the work of counselors as a science, and continuously improve the professionalism and specialization level on counselors.

Keywords: Counselors, Professionalism, Specialization

\section{关于提升辅导员队伍职业化和专业化水平的思考}

张硕 $^{1}$, 徐萱 ${ }^{2}$, 路慧 ${ }^{3}$, 刘斌 ${ }^{3}$, 韩晓雨 ${ }^{1}$, 于贵书 ${ }^{1}$

${ }^{1}$ 建设工程学部, 大连理工大学, 大连, 中国

教务处, 大连理工大学, 大连, 中国

软件学院, 大连理工大学, 大连, 中国

邮箱

zhangshuo@dlut. edu.cn (张硕)，xuxuan@dlut. edu. cn（徐萱）， luhui@dlut.edu. cn（路慧），laohubinbin@163.com（刘斌）， 108835 693@qq. com（韩晓雨），1002535403@qq. com（于贵书）

摘要: 《中共中央国务院关于进一步加强和改进大学生思想政治教育的意见》等各类纲领性文件明确提出要提高辅导 员队伍专业化、职业化水平。为此, 辅导员应该立足本职、注重实效、创新载体、加强学习, 将 “立德树人” 作为工 作的根本、强化工作的内涵式发展、充分发挥网络主渠道的作用、将辅导员工作上升为科学, 不断提升辅导员队伍的 职业化和专业化水平。

关键词: 辅导员队伍, 职业化, 专业化 


\section{1. 引言}

《中共中央国务院关于进一步加强和改进大学生思 想政治教育的意见》 [1] 明确指出 “要统筹规划专职辅导 员的发展。鼓励和支持一批骨干攻读相关学位和业务进修, 长期从事辅导员工作，向职业化、专家化方向发展。”《高 校辅导员职业能力标准 (暂行)》[2] 的颁布也旨在 “进 一步加强高校辅导员队伍建设, 推进辅导员队伍专业化、 职业化发展, 提升大学生思想政治教育工作质量。”但是, 各个高校落实辅导员队伍建设的相关文件的情况参差不 齐, 甚至有部分高校仅将辅导员作为学生的 “保姆”、

“管家” 等。为了更好的思考如何提升辅导员队伍的职业 化和专业化水平, 笔者仔细学习和研究了中央十六号文件、 教育部24号令 [3]、《高校辅导员职业能力标准 (暂行)》、

《关于进一步加强和改进新形势下高校宣传思想工作的 意见》 [4]、十八大报告 [5]等各类纲领性文件，分析了当 前思想政治教育工作的新形势、新问题，结合辅导员工作 的实际特点和问题, 探讨了辅导员队伍专业化和职业化提 升的四大切入点, 并进行了深入的探讨和分析。

\section{2. 立足本职, 将 “立德树人” 作为工作的根本任 务}

党的十八大提出, 把立德树人作为教育的根本任务, 培养学生社会责任感、创新精神和实践能力, 对坚持育人 为本、德育为先提出更高要求, 深化了大学生思想政治教 育的重要地位, 精辟的回答了“培养什么人, 怎样培养人” 这个根本问题。

\section{1 . 坚持 “育人为本, 德育为先”}

《高校辅导员职业能力标准 (暂行) 》(以下简称《标 准》) 中对辅导员进行了定义, 明确指出 “辅导员是开展 大学生思想政治教育的骨干力量, 是高校学生日常思想政 治教育和管理工作的组织者、实施者和指导者。辅导员应 当努力成为学生的人生导师和健康成长的知心朋友”。[2] 因此, 辅导员更要将 “德育” 作为工作的首要任务。在中 国特色社会主义理论体系的指导下, 将社会主义核心价值 观教育融入到学生教育管理的全过程, 对大学生进行理想 信念教育、文明道德修身教育, 引导广大学生树立高尚的 道德情操, 养成文明的行为规范, 建立积极的人生态度, 使其成为对民族、社会和未来富有强烈责任感、具有较高 道德品质的精英人才。为此, 辅导员要在不同层面开展道 德教育。

充分发挥党组织优势。在学生党员中开展党员形象示 范工程, 坚持以学生党员为点, 以学生党支部为线, 以积 极分子和全体学生为面, 通过科学全面的培养体系, 开展 “红色理论先锋营”等模式, 学习党的纲领性文件和政策, 积极开展形式多样、内容丰富、贴近青年特点的理论学习, 坚定学生党员的政治思想。

着重培养团学干部群体。团学干部是学生中的精英和 代表, 辅导员应该着重对其进行道德教育。为此, 应该在 学生干部中通过开展三级团校培训, 着重建设青马工程,
加强对学生干部的培养和引导, 使他们树立崇高的理想, 培养他们高尚的道德情操。

拓宽学生道德教育的渠道。在学生中开展道德修身教 育, 以《公民道德建设实施纲要》 [6] 为准则, 大力宣扬 “爱国守法、明礼诚信、团结友善、勤俭自强、敬业奉献” 的二十字基本道德规范, 倡导富强、民主、文明、和谐, 倡导自由、平等、公正、法治，倡导爱国、敬业、诚信、 友善, 积极培育社会主义核心价值观, 开展 “和谐校园 你 我共建” 道德修身活动月、“廉洁在我身边” 短剧大赛等 各类主题教育活动, 教育引导广大学生认识到实现中华民 族伟大复兴是中华民族近代以来最伟大的梦想, 认识到每 个人的前途命运都与国家和民族的前途命运紧密相连, 认 识到空谈误国, 实干兴邦。

\section{2. 培养大学生的综合素质}

十八大报告明确指出 “全面实施素质教育, 深化教育 领域综合改革, 着力提升教育质量, 培养学生社会责任感、 创新精神和实践能力”。[5]这也为辅导员工作提出新挑 战, 要求辅导员对学生进行 “德育” 教育的同时, 也要注 重 “树人”，提升大学生的综合素质。

辅导员在开展学生培养的过程中, 不仅要引导学生夯 实基础, 更要激发学生谋划和引领社会发展的责任感和追 求, 在学生中开展班会、征文等责任担当主题教育, 在校 园文化、社会实践渗透责任担当的精神内涵和道德尺度, 并将之转化为勇担责任、服务社会、关爱他人等实际行动; 教育引导学生培养学生创新精神和实践能力, 注重培养学 生的创新意识、创新精神、创新品质, 坚定创新信念; 推 进实践育人工作, 引导学生在实践中发现新知、运用真知, 在解决实际问题的过程中增长才干, 不断提高实践能力、 创新创业能力。 [7]

青年时国家的未来，是民族的希望，青年兴则国兴， 辅导员一定要抓好 “立德树人” 这个根本, 不断提高自身 工作水平, 将社会主义核心价值观教育落实、落小、落细, 使其深化到大学生的眼中、脑中和心中, 并真正成为学生 的行动指南。

\section{3. 注重实效, 强化工作的内涵式发展}

党的十八大明确指出, 要 “推动高等教育的内涵式发 展”，确立了新的历史时期高等教育科学发展的方向。“内 涵式发展” 是以事物的内部因素作为动力和资源的发展模 式, 表现为事物内在属性的发展, 如结构协调、要素优化、 质量提升、水平提高、实力增强等。归根结底, 高等教育 的内涵式发展应当是以提高质量为核心。[8]围绕这一战 略部署, 辅导员要进一步深入思考, 如何进一步提升自身 的工作质量, 实现内涵式发展。

作为一名高校辅导员, 日常工作繁杂、琐碎, 涉及到 大学生奖学金评比、困难生认定、助学金发放、学业指导、 班级管理、党员培养、特殊问题处理等方方面面, 在高等 教育向内涵式发展的今天, 辅导员也应该从被教育者的实 际出发, 建章立制, 坚持导向性、科学性和操作性, 运用 
多媒体等各类信息化手段, 不断简化工作流程, 不断提升 工作质量, 提高工作的科学化水平。

\section{1. 坚持 “以学生为本” ，增强教育手段的针对性}

十八大报告提出 “为人民服务是党的根本宗旨, 以人 为本、执政为民是检验党一切执政活动的最高标准” , 为 此, 辅导员必须把 “以人为本” 作为工作的最高标准, 坚 持 “以学生为本” , 研究受教育者在新的时代背景下的特 点, 不断改变教育手段, 采用学生喜闻乐见的方式, 如: 团体辅导、网络思政、文体活动等各类方式, 增强教育的 针对性。

\section{2. 坚持 “化繁为简”, 推进教育方式的精细化}

辅导员经常会沉没在繁杂、琐碎的工作之中，占用大 量的时间和精力, 使辅导员不能够沉下心思考工作，一定 程度上限制了辅导员工作的质量。为此，如何“化繁为简”, 使辅导员从繁琐的事务性工作解脱出来便成为思政工作 者思考的重要问题。通过多年探索, 笔者认为可以将学生 的基本信息、评奖评优系统、助学系统、学业系统纳入到 统一的数据库之中, 采取信息化方式提升工作效率; 可以 将每项工作进行系统化梳理, 尝试从精细化入手, 将教育 融入到细致的服务和关爱中去, 增强辅导员工作质量, 推 进辅导员工作内涵式发展。

\section{3. 坚持 “成才导向”, 注重教育效果的实效性}

帮助大学生成长成才是辅导员工作的重要目标, 为此, 辅导员要不断提升自身的工作水平, 在明确目标、改进方 法的基础上，更加注重教育效果的实效性。通过问卷、访 谈等形式反馈学生对于辅导员工作的认可度和需求度, 通 过学生的毕业去向、未来发展轨迹等方式反馈辅导员工作 的效果, 使辅导员思考自身工作中存在的问题, 调整思路, 结合学生成长的实际情况, 提高自身工作质量, 不断推进 工作的内涵式发展。

\section{4. 创新载体, 充分发挥网络主渠道的作用}

当代大学生成长于互联网快速发展的时代, 网络已是 高校学生获取社会信息的主要渠道和休闲娱乐的重要途 径。“每日必网” “、无网不在”已成为当前很多大学生 的生活写照。大多数学生能够遵守网络道德, 但仍有相当 一部分学生沉迷网络游戏、传播不良信息等, 影响了学生 身心健康和成长成才。为此, 辅导员要坚持 “趋利” 与 “避 害” 相结合、“管理”与 “疏导” 相结合、“教育”与 “服 务” 相结合, 主动占领网上思想文化阵地。

一方面, 引导学生关注网络主阵地。积极引导学生加 入到 “中国大学生在线”、“辽宁省大学生在线联盟” “大 工新闻网” 等主流教育阵地, 通过学生党支部、学生团支 部、学生社团、团学组织等在主流阵地上建立团队博客、 微信公共平台等方式, 鼓励学生们向湖南大学团队博客 “金大团” 博客学习, 增强学生们对主阵地的关注度, 潜 移默化对学生们进行思想教育。
另一方面, 提高自身的网络工作能力。在大学生在线 联盟上建立辅导员博客, 不断提升自身的写作、摄影水平, 发表网络思政博文, 发布或转载优秀散文、诗歌、摄影、 微电影等文学、艺术作品, 对学生进行思想教育。同时, 充分利用学生喜闻乐见的QQ、微信、微博等形式对学生进 行 “网络春雨”、“网络家访”, 将网上、网下工作有机 结合, 充分利用重大节庆日和纪念日加强网上主题教育, 把思想政治教育内容融入大学生网上生活, 开创大学生思 想政治教育网上、网下互动、互补的良好局面, 努力实现 全方位育人。

\section{5. 加强学习, 将辅导员工作上升为科学}

《标准》中明确规定了辅导员需要掌握的基础知识和 职业知识, 对辅导员的职业能力标准进行了明确规定, 为 此, 辅导员要紧密围绕《标准》的相关要求, 不断的提升 自身水平, 结合自身工作实践, 加强理论学习, 将零散的 工作系统化, 将粗浅的认识深刻化, 努力向专职业化、专 业化的思政辅导员迈进。

一是要着力研究受教育者的特点, 把握思政教育的规 律。作为一名思想政治教育工作者, 首先应该结合受教育 者所在的国内国际环境和成长的时代背景, 了解并掌握受 教育者在学业、心理、就业、规划、素质提升等方面的特 点, 通过问卷调查、案例分析等方式开展研究工作, 以更 好的提升工作的针对性和实效性。

二是要着力研究思想政治教育领域中的前沿问题。订 阅《思想政治教育研究》、《思想理论研究》等思想政治 教育领域内比较权威的核心期刊, 定期查阅中国期刊全文 数据库的一些经典文章, 及时学习和掌握党和国家的相关 政策, 了解和掌握大学生思想政治教育工作中的难点、热 点和前沿问题, 并结合自身的工作实际深入开展理论, 并 注重将研究成果转化应用。

三是要不断丰富自身的知识结构。学习和掌握马克思 主义理论学科和思想政治教育学科的重要理论, 同时积极 学习哲学、政治学、管理学、心理学、社会学等学科的方 法和知识, 以跨学科的视野研究辅导员的实际问题, 强化 问题导向, 不断完善自身的理论基础, 为实现工作的科学 化和专业化提供坚实的理论支撑。[9]

\section{6. 结论与建议}

当前国际的政治、经济格局处于一个大调整、大变革 的重要时期, 各种社会思潮和社会矛盾对学生的思想影响 和干扰比较多。这为辅导员工作提出了新要求、新呼唤和 新使命, 辅导员要适应潮流, 不断学习, 强化工作内涵式 发展, 不断提升队伍的职业化和专业化水平, 为培养社会 主义合格建设者和可靠接班人贡献力量。[10]

\section{致谢}

本文为大连理工大学2014年教育教学改革基金课题 (学生工作研究) 《辅导员工作 “课程化” 建设研究》 
阶段性研究成果

\section{参考文献}

１１《中共中央国务院关于进一步加强和改进大学生思想政治 教育的意见》 $[\mathrm{EB} / \mathrm{OL}]$.

http://baike. baidu. com/1 ink?url=oxX0aHJ71y3RGYCE5P m00Vy jmfvQZDBGt8oFVH3sZn2Y8jVv_Wgg jvY2j-nXRPsJTdk6 k4 jgy9-bZy-WMBkkQq

[2]《高校辅导员职业能力标准 (暂行)》. [EB/OL]. http://www. gov. cn/xinwen/2014-04/14/content_265861 6. htm

[3]《普通高等学校辅导员队伍建设规定》 $[\mathrm{EB} / \mathrm{OL}]$. http://www. gov. cn/flfg/2006-07/31/content_350701.h tm

４4《关于进一步加强和改进新形势下高校宣传思想工作的意 见》
[EB/OL]. http://education. news. cn/2015-01/19/c_1114 051345. htm

［5］胡锦涛. 坚定不移沿着中国特色社会主义道路前进为全面 建成小康社会而奋斗一一在中国共产党第十八次全国代表 大会上的报告 [M]. 北京: 人民出版社，2012。

[6]《公民道德建设实施纲要》 [EB/OL]. http://news. xinhuanet. com/video/2006-09/18 /content_5106156.htm

[7]《大学生思想政治教育的新内涵、新使命、新要求》, 黄 艳、 成黎明《中国高等教育》2013年8月，11-13。

[8] 《高等教育内涵式发展的实现途径》, 㫿振元《中国高等 教育》2013年2月, 12-14。

［9］《学习贯彻党的十八大精神努力提升大学生思想政治教育 质量》冯刚《思想理论教育导刊》2013年第2期, 44-49。

[10］冯刚. 《辅导员工作培训教程》 [M], 高等教育出版社, 2013。 